\title{
Virulence regulon polymorphism in group $A$ streptococci revealed by long PCR and implications for epidemiological and evolutionary studies
}

\author{
J. V. HOOKEY, N. A. SAUNDERS, J. P. CLEWLEY, ANDROULLA EFSTRATIOU* and R. C. GEORGE* \\ Molecular Biology Unit, Virus Reference Division and * Streptococcus and Diphtheria Reference Unit, \\ Respiratory and Systemic Infection Laboratory, Central Public Health Laboratory, Colindale, London NW9 5HT
}

\begin{abstract}
A method based on long PCR amplification and restriction endonuclease analysis of the virulence regulon was developed for a rapid ( 2 days), simple differentiation of group $A$ streptococci. The PCR product size varied from $12.3 \mathrm{~kb}$ for serotypes M1 (NCTC 8198) and M12 (NCTC 10085) to $7.8 \mathrm{~kb}$ for serotype M6 (NCTC 8302). The fragment patterns formed on Hae III digestion of the products were unique and this allowed the differentiation of each of the M-type strains (M1, M3, M4, M5, M6, M11, M12, M28, M76 and M78) studied. Contemporary M1 isolates all gave the same fragment pattern but differed from the prototype strain (NCTC 8198) in not having a 1.25-kb fragment. Isolates of serotypes $\mathrm{M} 1$ and $\mathrm{M3}$ each had similar patterns, an indication of their clonality and global dispersion. In contrast, more than one restriction fragment length polymorphism (RFLP) pattern was detected among clinical isolates of serotypes M5, M6, M12, M4, M(R)28 and M78. Two strains that were M-protein non-typable by serological means were provisionally classified as M6 by comparisons of Hae III long PCR fragment patterns.
\end{abstract}

\section{Introduction}

Streptococcus pyogenes (Lancefield group A $\beta$-haemolytic streptococcus; GAS) is a ubiquitous and versatile human pathogen. Typical clinical presentations include pharyngitis, scarlet fever, impetigo and, more rarely, necrotising fasciitis and myositis. The non-suppurative sequelae, glomerulonephritis and acute rheumatic fever, are leading causes of morbidity and mortality in many areas of the developing world [1,2]. Recently, a toxic shock-like streptococcal syndrome has been associated with invasive strains $[3,4]$. Despite the availability of effective antibiotics and supportive therapy, GAS continues to cause serious invasive diseases with significant mortality [5-8]. Recent publicity generated in response to cases of necrotising fasciitis and myositis also served to focus attention on diseases caused by GAS [9].

The most commonly accepted method of characterisation of streptococcal strains is by serological identification of the $\mathrm{T}$ and $\mathrm{M}$ proteins $[10,11]$. Characterisation may also be accomplished by the detection of serum opacity factor $(O F)$, consistently associated with specific $M$ proteins [12-15]. Absorbed typing antisera against cell-surface $M$ proteins divide GAS into c. 100 distinct types. However, because M

Received 12 Feb. 1996; accepted 18 Feb. 1996.

Corresponding author: Dr J. V. Hookey. antisera are unavailable commercially and their preparation is laborious and costly, $\mathrm{M}$ typing has become restricted to a few specialised laboratories. Furthermore, c. $10 \%$ of strains in the UK are M protein nontypable, either because of diminution or loss of $\mathrm{M}$ protein expression, in-vitro proteinase digestion or the lack of availability of appropriate antisera $[6,7]$.

To overcome these limitations alternative typing methods have been developed. These have included phenotypic methods such as bacteriophage and bacteriocin typing and multilocus enzyme electrophoresis [16-19]. More recently, several genotypic DNAbased methods have been applied with varying degrees of success. These have included restriction endonuclease analysis, pulsed-field gel electrophoresis (PFGE) and ribotyping [20-23], all of which are technically demanding and time-consuming.

The main virulence determinants of GAS, including $M$ proteins, immunoglobulin Fc-receptors and C5a peptidase, are located within a virulence regulon [24]. The $\mathrm{emm}$ and $\mathrm{emm}$-like genes (c. $1.5 \mathrm{~kb}$ in size) encoding the $\mathrm{M}$ and $\mathrm{M}$-like proteins are flanked $\left(5^{\prime}-3^{\prime}\right)$ by the $\operatorname{vir}(c .1 .5 \mathrm{~kb})$ and the $\operatorname{scp} A(c .4 .4 \mathrm{~kb})$ genes [25-28].

The application of PCR to the typing of microorganisms is well documented but there have been few reports of the amplification of DNA targets $>4-5 \mathrm{~kb}$. However, Barnes recently reported the amplification of 
DNA up to $45 \mathrm{~kb}$ ('long' PCR) with an enhanced proof-reading DNA polymerase [29]. This study presents a protocol for the characterisation and differentiation of GAS that is technically easy to perform and can be done in 2 days, based on PCR amplification of up to $12.3 \mathrm{~kb}$ and restriction endonuclease analysis of the virulence regulon.

\section{Materials and methods}

\section{Strains}

Ten M-type strains, 67 contemporary clinical isolates from different geographical areas within the UK and nine strains that were $\mathrm{M}$-protein non-typable were analysed. Two duplicate strains were included (Table 1). Stock clinical cultures were maintained in blood glycerol broth $(16 \% \mathrm{v} / \mathrm{v})$ at $-70^{\circ} \mathrm{C}$.

\section{DNA preparation}

Bacteria were grown on blood agar at $37^{\circ} \mathrm{C}$, in an aerobic atmosphere overnight. The bacteria were harvested and suspended into $1 \mathrm{ml}$ of $0.2 \mathrm{M}$ sodium acetate buffer ( $\mathrm{pH} \mathrm{6.0)}$ ) and centrifuged at $7500 \mathrm{~g}$ for $10 \mathrm{~min}$. The pellet was resuspended in $100 \mu \mathrm{l}$ of mutanolysin $(40 \mu \mathrm{g} / \mathrm{ml}$ in $980 \mu \mathrm{l}$ of $1 \mathrm{mM}$ EDTA, $\mathrm{pH}$ 8.0, $10 \mathrm{mM}$ Tris- $\mathrm{HCl}, \mathrm{pH} 8.0)$ and $50 \mu \mathrm{l}$ of fresh lysozyme $(50 \mathrm{mg} / \mathrm{ml})$ and incubated at $37^{\circ} \mathrm{C}$ for $4 \mathrm{~h}$. Chromosomal DNA was then extracted after lysis with freshly prepared guanidium isothiocyanate reagent [30].

\section{Long PCR amplification of the virulence regulon}

Chromosomal DNA ( $\mathrm{A}_{260}$ c. 500-250 ng) was amplified by PCR with an XL ${ }^{\text {Tm }}$ PCR kit (Perkin Elmer, Applied Biosystems) with primers designed for the entire virulence regulon (Primer ${ }^{\mathrm{Tm}}$ computer program, C. W. Dieffenbach, Department of Surgery and Pathology, Uniformed Services University of the Health Sciences, Bethesda, MD, USA): 5'CTA AAC CGT ATC TTT GAC GCA CT3' (339-363, nucleotide sequence numbering 720 base pairs upstream from the start of the vir gene ORF [26]) and 5'TTG ATG CTT TTG TAG CTA AAG CAC3' (4189-4213 numbering of the scpA gene [27]). Each amplification mixture in sterile thin-walled PCR tubes (Perkin Elmer, Applied BioSystems) comprised template DNA, 12.5 pmol of each primer, $50 \mu \mathrm{M}$ of each dNTP (dATP, dCTP, dGTP and TTP), $1 \times \mathrm{XL}$ buffer, $0.75 \mathrm{mM} \mathrm{Mg}(\mathrm{OAc})_{2}$, (Analar, $\mathrm{BDH}) 2.5 \% \mathrm{v} / \mathrm{v}$ glycerol and $\mathrm{r}$ th $\mathrm{DNA}$ polymerase 1.5 units. Filter-sterilised $(0.22 \mu \mathrm{m})$ water was added to a final volume of $50 \mu \mathrm{l}$ and the reaction was overlayed with $75 \mu \mathrm{l}$ of mineral oil (Sigma).

Thermal cycling was done on a Perkin Elmer model 480 cycler following a 'hot start' at $80^{\circ} \mathrm{C}$. Guidelines for amplification were given by the manufacturers. Two linked programmes were used: firstly, denaturation at $94^{\circ} \mathrm{C}$ for $10 \mathrm{~s}$ and annealing extension at $62^{\circ} \mathrm{C}$ for $6.5 \mathrm{~min}$ for 20 cycles; secondly, $94^{\circ} \mathrm{c}$ for $10 \mathrm{~s}$ and annealing extension at $62^{\circ} \mathrm{C}$ for $7.5 \mathrm{~min}$ with a $13-\mathrm{s}$ auto-segment extension at each step for 12 cycles. A final step at $72^{\circ} \mathrm{C}$ for $10 \mathrm{~min}$ was used. The aqueous PCR product was removed by the addition of chloroform $(100 \mu \mathrm{l})$ and stored at $4^{\circ} \mathrm{C}$.

\section{$D N A$ restriction endonuclease analysis of the $P C R$ amplified virulence regulon}

Approximately $500 \mathrm{ng}(5-7 \mu \mathrm{l})$ of PCR product was digested with 2 units of restriction endonucleases (Boehringer Mannheim) at $37^{\circ} \mathrm{C}$ for $1.5 \mathrm{~h}$. The enzymes Asp700, Bam HI, Dra I, Eco RI, Hind III, Hpa I and Hae III were used. Twenty $\mu \mathrm{l}$ of digested PCR product was analysed by gel electrophoresis in molecular biology grade agarose (BioRad) $0.8 \%$, w/v in Tris-acetate-EDTA buffer, $\mathrm{pH} 8.0$, at $35 \mathrm{~mA}$ for $20 \mathrm{~h}$. The fragment sizes were computed from their migration distances against the reference standards Hind III/Lambda bacteriophage DNA and $\varnothing \mathrm{X} 174$ replicative form (RF) DNA/Hae III fragment markers (BioRad). For schematic representations, fragment patterns were plotted on a $\log _{10}$ scale.

\section{Results}

Oligonucleotide primers were designed for long PCR amplification of the entire virulence regulon, including the vir, emm and $s c p A$ genes, from reference $M$ types, contemporary isolates and $\mathrm{M}$-protein non-typable strains (Table 1). The largest product size was $12.3 \mathrm{~kb}$ from types M1 and M12 and the smallest was $7.8 \mathrm{~kb}$ for $M$ type 6 (Fig. 1).

The patterns generated by DNA restriction endonuclease digestion with Hae III were unique for each type strain studied (Figs. 2 and 3). The number of fragments produced varied from 10 for type M1 to four for types M3 and M6. Fragment sizes varied from $4.4 \mathrm{~kb}$ (M6) to $c .400 \mathrm{bp}$ (M1, M5, M6, M4 and M11; Fig. 3). The mean values (SD) for within-gel errors $(\mathrm{n}=3)$ for type M5 (NCTC 100065) were 2.11 $(50 \mathrm{bp}) \mathrm{kb} 1.90$ (50), 1.80 (20), 1.20 (50), 1.15 (10) and $0.385(10 \mathrm{bp}) \mathrm{kb}$ for the six products. For strain M12-2681 they were 2.20 (50 bp) kb 2.00 (50), 1.60 (50), $1.30(50), 1.16(40), 0.86(20) \mathrm{kb}$ and 0.58 (20 bp) $\mathrm{kb}$ for the seven bands (Fig. 3). Other enzymes specific for A-T rich DNA such as Asp700, Bam HI, Dra I, Eco RI, Hind III and Hpa I were less discriminatory (data not shown). There was no Eco RI cutting site within the regulon. All strains examined shared a common 1.15-kb 'core' fragment, the significance of which is not clear (Fig. 3).

The fragment patterns for contemporary clinical isolates from different geographical regions within the UK were examined (Table 1; Fig. 3). Twenty-five distinct 
Table 1. Strains of GAS examined and their RFLP pattern on Hae III digestion of the virulence regulon

\begin{tabular}{|c|c|c|c|}
\hline M-type strain & Place of isolation & Disease* $^{*}$ & RFLP pattern \\
\hline M1, NCTC 8198 & London & Scarlet fever & 1 \\
\hline $\begin{array}{l}\text { M1-0002 } \\
\text { M1-0528 } \\
\text { M1-1037 } \\
\text { M1-2025 } \\
\text { M1-2365 } \\
\text { M1-3102 } \\
\text { M1-1020 } \\
\text { M1-1301 } \\
\text { M1-2082 }\end{array}$ & $\begin{array}{l}\text { Barnstable } \\
\text { Bishop Auckland } \\
\text { Kettering } \\
\text { London, hospital A } \\
\text { Bedford } \\
\text { Stoke } \\
\text { Croydon } \\
\text { Gateshead } \\
\text { Nottingham }\end{array}$ & $\begin{array}{l}\text { Cellulitis } \\
\text { Fatal pneumonia } \\
\text { Scarlet fever } \\
\text { Cellulitis, TSLS } \\
\text { Fatal TSLS } \\
\text { Pneumonia } \\
\text { Pressure sore } \\
\text { Septicaemia } \\
\text { Cellulitis }\end{array}$ & $1 \mathrm{~A}$ \\
\hline M3, NCTC 100064 & - & - & 3 \\
\hline $\begin{array}{l}\text { M3-0671 } \\
\text { M3-1806 } \\
\text { M3-2022 } \\
\text { M3-2461 } \\
\text { M3-2594 } \\
\text { M3-1463 } \\
\text { M3-1824 } \\
\text { M3-2074 }\end{array}$ & $\begin{array}{l}\text { Exeter } \\
\text { London, hospital B } \\
\text { High Wycombe } \\
\text { Southend } \\
\text { Nottingham } \\
\text { Plymouth } \\
\text { Belfast } \\
\text { Stoke-on-Trent }\end{array}$ & $\begin{array}{l}\text { Gangrene } \\
\text { Puerperal sepsis } \\
\text { Cellulitis } \\
\text { Cellulitis } \\
\text { Septicaemia } \\
\text { Infected eczema } \\
\text { Pneumonia } \\
\text { Septicaemia }\end{array}$ & 3 \\
\hline M5, NCTC 100065 & - & - & 5 \\
\hline M5-1024 & Blackburn & Fatal endocarditis & $5 \mathrm{~A}$ \\
\hline M5-1563 & London, hospital C & Fatal septicaemia & $5 \mathrm{~B}$ \\
\hline $\begin{array}{l}\text { M5-0321 } \\
\text { M5-1111 } \\
\text { M5-1390 }\end{array}$ & $\begin{array}{l}\text { Kettering } \\
\text { Lanarkshire } \\
\text { London, hospital D }\end{array}$ & $\begin{array}{l}\text { TSLS } \\
\text { Cellulitis } \\
\text { Pneumonia }\end{array}$ & $5 \mathrm{C}$ \\
\hline $\begin{array}{l}\text { M5-0145 } \\
\text { M5-1479 }\end{array}$ & $\begin{array}{l}\text { High Wycombe } \\
\text { Leicester }\end{array}$ & $\begin{array}{l}\text { Puerperal sepsis } \\
\text { Cellulitis }\end{array}$ & $5 \mathrm{D}$ \\
\hline M5-1906 & Glasgow & Septicaemia & $5 \mathrm{E}$ \\
\hline M5-0581 & Wigan & TSLS & $5 \mathrm{~F}$ \\
\hline M6, NCTC 8302 & - & - & 6 \\
\hline $\begin{array}{l}\text { M6-1006 } \\
\text { M6-1411 }\end{array}$ & $\begin{array}{l}\text { Bishop Auckland } \\
\text { Coventry }\end{array}$ & $\begin{array}{l}\text { Septicaemia } \\
\text { Cellulitis }\end{array}$ & 6 \\
\hline $\begin{array}{l}\text { M6-2544 } \\
\text { M6-1521 } \\
\text { M6-2095 }\end{array}$ & $\begin{array}{l}\text { London, hospital D } \\
\text { Worthing } \\
\text { Ashford }\end{array}$ & $\begin{array}{l}\text { Septicaemia } \\
\text { Necrotising fasciitis } \\
\text { Septicaemia }\end{array}$ & $6 \mathrm{~A}$ \\
\hline $\begin{array}{l}\text { M6-1431 } \\
\text { M6-0828 }\end{array}$ & $\begin{array}{l}\text { Nottingham } \\
\text { South Shields }\end{array}$ & $\begin{array}{l}\text { Endocarditis } \\
\text { Septicaemia }\end{array}$ & $6 \mathrm{~B}$ \\
\hline M12, NCTC 10085 & - & - & 12 \\
\hline $\begin{array}{l}\text { M12-0753 } \\
\text { M12-1628 } \\
\text { M12-2629 } \\
\text { M12-2681 } \\
\text { M12-0180 } \\
\text { M12-1564 }\end{array}$ & $\begin{array}{l}\text { Harrogate } \\
\text { Sheffield } \\
\text { Wolverhampton } \\
\text { Cambridge } \\
\text { Dundee } \\
\text { Taunton }\end{array}$ & $\begin{array}{l}\text { Septicaemia } \\
\text { Leukaemia/Rash } \\
\text { Septicaemia } \\
\text { Septicaemia } \\
\text { None given } \\
\text { None given }\end{array}$ & 12 \\
\hline $\mathrm{M} 12, \mathrm{NG}$ & Wolverhampton & Septicaemia & $12 \mathrm{~A}$ \\
\hline M4, NCTC 8326 & - & - & 4 \\
\hline $\begin{array}{l}\text { M4-1352 } \\
\text { M4-0115 } \\
\text { M4-2099 }\end{array}$ & $\begin{array}{l}\text { Oxford } \\
\text { Reading } \\
\text { Birmingham }\end{array}$ & $\begin{array}{l}\text { Endocarditis } \\
\text { None given } \\
\text { Cellulitis }\end{array}$ & 4 \\
\hline $\begin{array}{l}\text { M4-2591 } \\
\text { M4-0112 } \\
\text { M4-0190 } \\
\text { M4-1785 }\end{array}$ & $\begin{array}{l}\text { Crawley } \\
\text { Devon } \\
\text { Livingston } \\
\text { Portsmouth }\end{array}$ & $\begin{array}{l}\text { Septicaemia } \\
\text { TSLS } \\
\text { Cellulitis } \\
\text { Septicaemia }\end{array}$ & $4 \mathrm{~A}$ \\
\hline M4-2737 & Devon & Arthritis & $4 \mathrm{~B}$ \\
\hline M11, NCTC 100068 & - & - & 11 \\
\hline $\begin{array}{l}\text { M11-0152 } \\
\text { M11-0181 } \\
\text { M11-1129 } \\
\text { M11-1554 }\end{array}$ & $\begin{array}{l}\text { Newcastle } \\
\text { Glasgow } \\
\text { Taunton } \\
\text { Wolverhampton }\end{array}$ & $\begin{array}{l}\text { Septicaemia } \\
\text { TSLS } \\
\text { Wound infection } \\
\text { Septicaemia }\end{array}$ & 11 \\
\hline $\mathrm{M}(\mathrm{R}) 28, \mathrm{NCTC} 8308$ & - & - & 28 \\
\hline $\begin{array}{l}M(R) 28-0133 \\
M(R) 28-2719 \\
M(R) 28-2929\end{array}$ & $\begin{array}{l}\text { York } \\
\text { Audley } \\
\text { Nottingham }\end{array}$ & $\begin{array}{l}\text { Septicaemia } \\
\text { Septicaemia } \\
\text { TSLS }\end{array}$ & \\
\hline
\end{tabular}


Table 1. (continued)

\begin{tabular}{|c|c|c|c|}
\hline M-type strain & Place of isolation & Disease* & RFLP pattern \\
\hline $\begin{array}{l}M(R) 28-0022 \\
M(R) 28-1713 \\
M(R) 28-1983 \\
M(R) 28-0211 \\
M(R) 28-0215 \\
M(R) 28-0217\end{array}$ & $\begin{array}{l}\text { London, hospital F } \\
\text { Nottingham } \\
\text { Norwich } \\
\text { Birmingham } \\
\text { Devon } \\
\text { Oxford }\end{array}$ & $\begin{array}{l}\text { Septicaemia } \\
\text { Cellulitis } \\
\text { Septic arthritis } \\
\text { Cellulitis } \\
\text { TSLS } \\
\text { Septicaemia }\end{array}$ & 28 \\
\hline$M(R) 28-3007$ & Stockton-on-Tees & Septicaemia & $28 \mathrm{~A}$ \\
\hline M76, NCTC 12056 & - & - & 76 \\
\hline $\begin{array}{l}\text { M76-0966 } \\
\text { M76-2592 } \\
\text { M76-2593 }\end{array}$ & $\begin{array}{l}\text { Oxford } \\
\text { Nottingham } \\
\text { Nottingham }\end{array}$ & $\begin{array}{l}\text { Septicaemia } \\
\text { Pneumonia } \\
\text { Pneumonia }\end{array}$ & 76 \\
\hline M78, NCTC 12058 & - & - & 78 \\
\hline M78-1131 & Clwyd & None given & $78 \mathrm{~A}$ \\
\hline M78-1636 & Harrow & None given & $78 \mathrm{~B}$ \\
\hline \multicolumn{4}{|c|}{$M$ protein non-typable strains (NT-) } \\
\hline $\begin{array}{ll}\text { NT } 318 \\
\text { NT } 406\end{array}$ & $\begin{array}{l}\text { Derry } \\
\text { Derry }\end{array}$ & $\begin{array}{l}\text { Pneumonia } \\
\text { Pneumonia }\end{array}$ & 6 \\
\hline $\begin{array}{l}\text { NT } 204 \\
\text { NT } 205\end{array}$ & $\begin{array}{l}\text { Uxbridge } \\
\text { Uxbridge }\end{array}$ & $\begin{array}{l}\text { None given } \\
\text { None given }\end{array}$ & NE \\
\hline $\begin{array}{ll}\text { NT } & 357 \\
\text { NT } & 358 \\
\text { NT } & 360\end{array}$ & $\begin{array}{l}\text { Oxford } \\
\text { Oxford } \\
\text { Oxford }\end{array}$ & $\begin{array}{l}\text { None given } \\
\text { None given } \\
\text { None given }\end{array}$ & $\mathrm{NE}$ \\
\hline NT 466 & London, hospital A & Fatal TSLS & $\mathrm{NE}$ \\
\hline NT 1136 & London, hospital B & Not given & NE \\
\hline
\end{tabular}

TSLS, toxic shock-like syndrome.

*Strains isolated from blood cultures in the UK, 1993-1994.

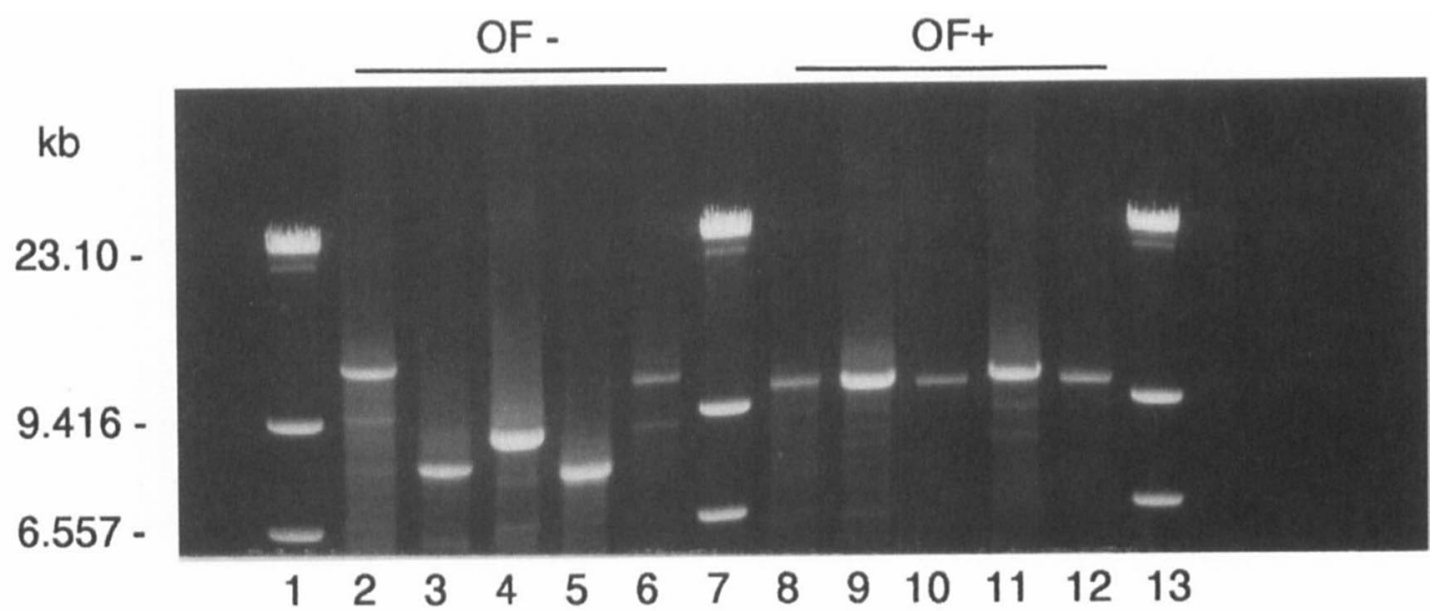

Fig. 1. Agarose gel analysis of long PCR amplified virulence regulon from representative GAS M type strains. Lanes 1, 7, 13, Hind III/lambda bacteriophage DNA marker; 2, M1 NCTC 8198; 3, M3 NCTC 100064; 4, M5 NCTC 100065; 5, M6 NCTC 8302; 6, M12 NCTC 10085; 8, M4 NCTC 8326; 9, M11 NCTC 100068; 10, M(R)28 NCTC 8308; 11, M76 NCTC $12056 ; 12$, M78 NCTC 12058. OF+, Production of serum opacity factor.

restriction fragment length polymorphism (RFLP) patterns were found among the 89 strains studied (Fig. 3). The M-protein non-typable strains gave distinct patterns. The nomenclature used for distinguishing patterns was the M-protein type followed by an RFLP pattern subtype. Thus, RFLP 5 corresponded to $\mathrm{M}$ protein type 5 strains and $5 \mathrm{~A}, 5 \mathrm{~B}, 5 \mathrm{C}, 5 \mathrm{D}, 5 \mathrm{E}, 5 \mathrm{~F}$ indicated subtype patterns within the M5 strains (Fig. 3).
The M1 isolates each showed identical Hae III RFLP profiles, although they differed from the prototype M1 strain (NCTC 8198) in not having a 1.25-kb fragment (Table 1; Fig. 3). Some isolates from a single $M$ type shared identical patterns, including those from types M1, M3, M11 and M76. In contrast, isolates of some types (M5, M6, M12, M4, M(R)28 and M78) gave dissimilar RFLP patterns (Fig. 3). The M5 isolates 


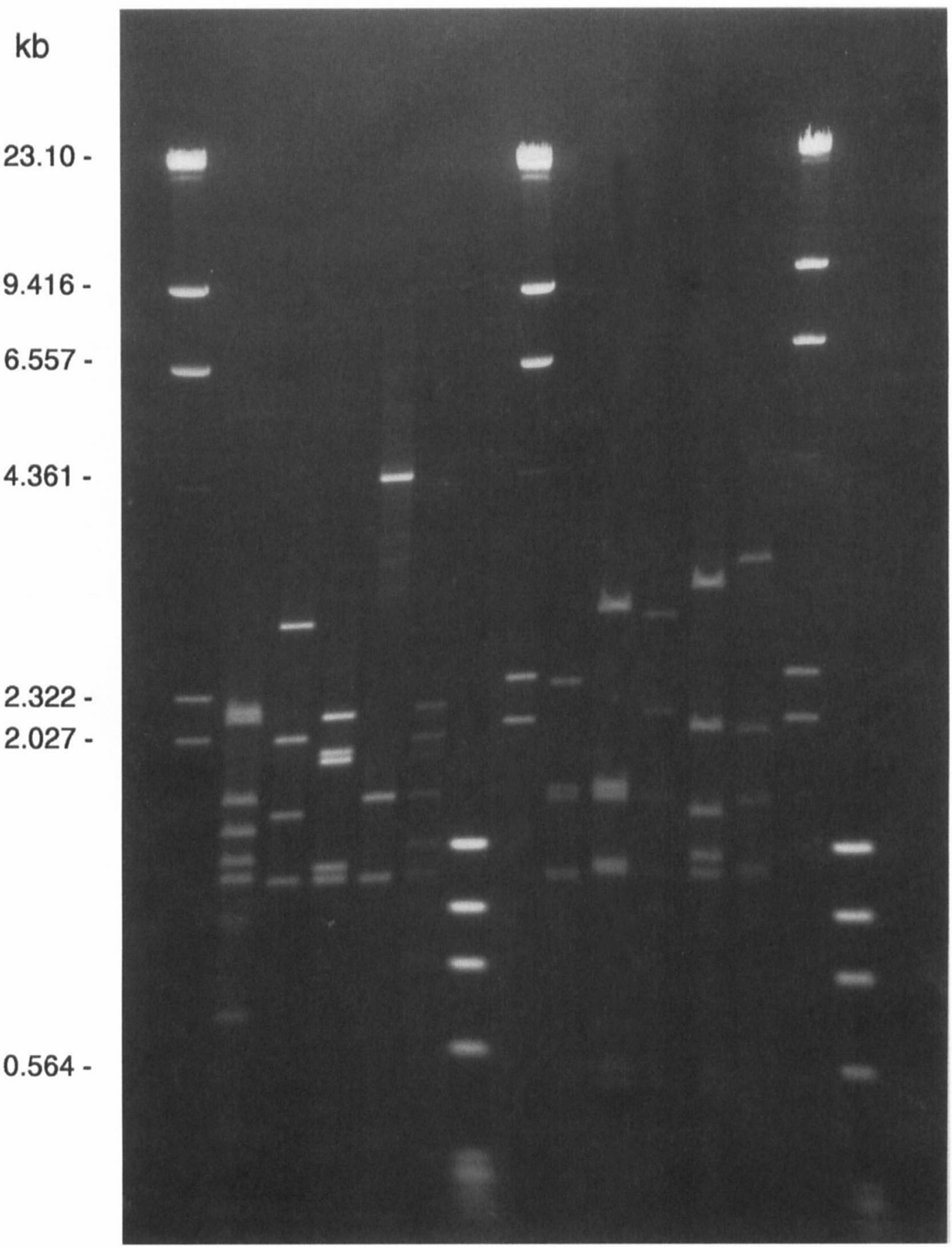

\section{$\begin{array}{lllllllllllllll}1 & 2 & 3 & 4 & 5 & 6 & 7 & 8 & 9 & 10 & 11 & 12 & 13 & 14 & 15\end{array}$}

Fig. 2. Agarose gel electrophoresis of long PCR amplified virulence regulon from representative GAS type strains digested with the restriction endonuclease Hae III. Lanes 1, 8, 14, Hind III/lambda bacteriophage DNA marker; 7, 15, OX174 RF DNA/Hae III marker; 2, M1 NCTC 8198; 3, M3 NCT 100064; 4, M5 NCTC 100065; 5, M6 NCTC 8302; 6, M12 NCTC 10085; 9, M4 NCTC 8326; 10, M11 NCTC 100068; 11, M(R)28 NCTC 8308; 12, M76 NCTC 12056; 13, M78 NCTC 12058.

gave six RFLP subtypes $(5 \mathrm{~A}-5 \mathrm{~F})$, whereas those from types $\mathrm{M} 12$ and $\mathrm{M}(\mathrm{R}) 28$ gave only two.

Most (78\%) of the M-protein non-typable strains showed unique patterns. Similar profiles were observed for NT 204, NT 205, NT 357, NT 358 and NT 360 (Fig. 3). Two strains, NT 318 and NT 406, had Hae III virulence regulon patterns similar to type M6 (Fig. 3).

\section{Discussion}

Recent cases of necrotising fasciitis and myositis within the UK have highlighted the need for surveillance of streptococcal infections and for identification and differentiation of strains of GAS [5, 9]. Genotyping by ribotyping and PFGE augments M-protein typing but both are technically complex and time-consuming [21-23]. 


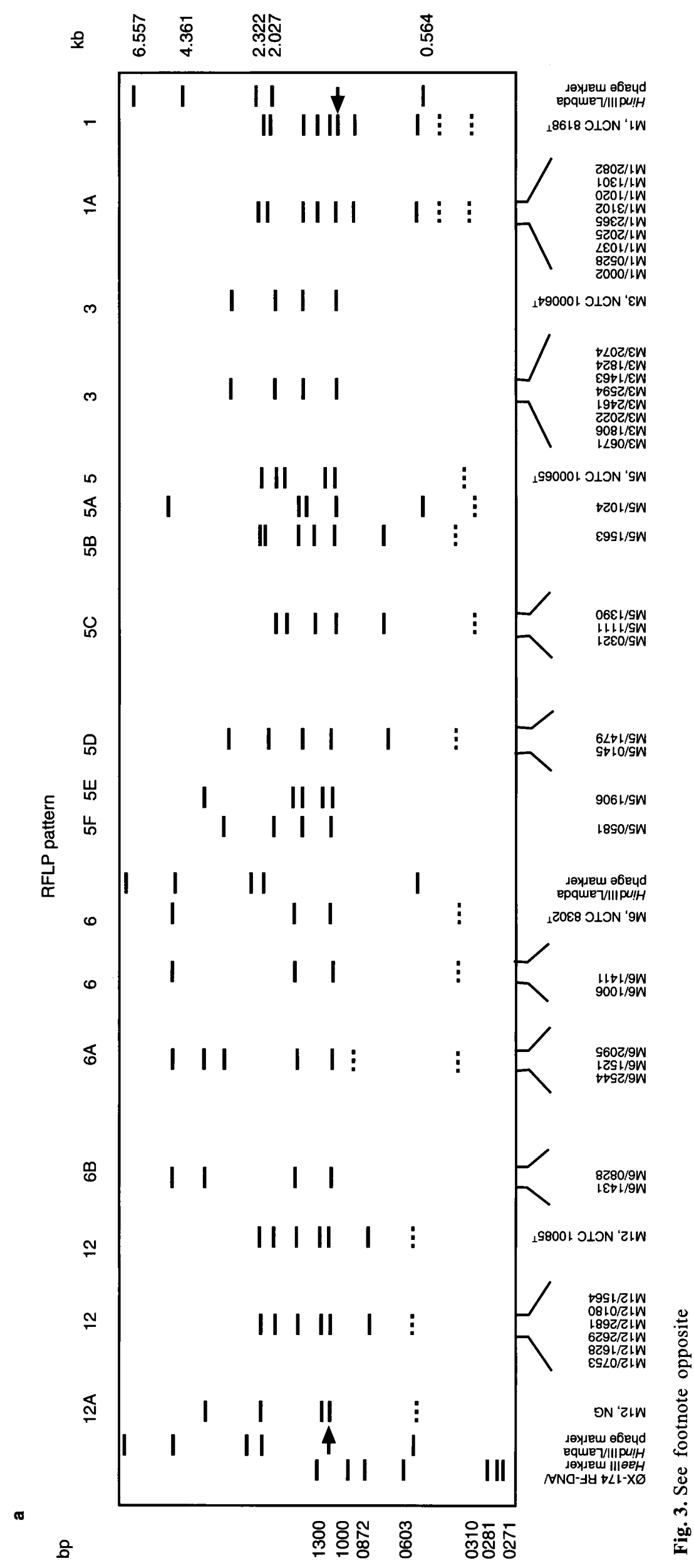




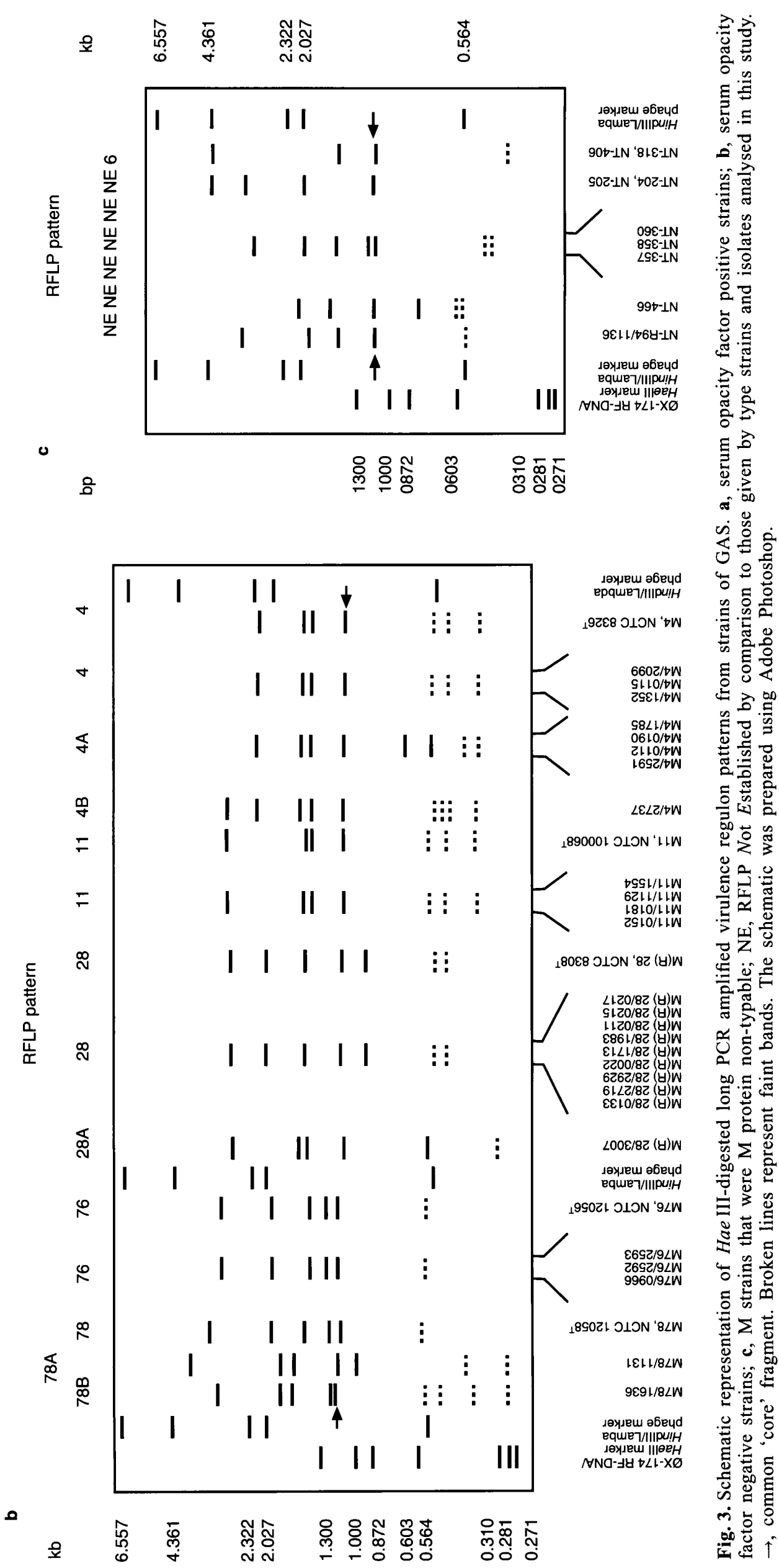


The antigenically variable $\mathrm{M}$ (encoded in the $\mathrm{emm}$ gene) and M-like (emm-L gene) proteins confer resistance to phagocytosis and the binding of immunoglobulins [31]. Transcription of emm, emm-L and scpA have been shown to be regulated by the virulence gene (vir), at a locus called the virulence regulon $[24,26,32-34]$.

Amplification by PCR with Taq DNA polymerase is mostly limited to DNA templates $<4-5 \mathrm{~kb}$, due partly to the absence of proof-reading $\left(3^{\prime}-5^{\prime}\right.$ exonuclease) activity in the Taq enzyme. PCR primers specific for the entire vir regulon combined with a DNA polymerase with proof-reading activity have been used sucessfully in this study to amplify the entire virulence gene of GAS.

While this work was in progress, Gardiner et al. reported the amplification of a 5-6.5-kb fragment of the virulence regulon with primers that did not fully encompass the virulence regulon [35]. The size of the vir regulon, excluding spacer sequences between the vir-emm (or emm-like) and scpA genes, is estimated at c. $7.5 \mathrm{~kb}$ [25-27]. In this report, similar-sized PCR products were observed for types M3 and M6 (Fig. 1). However, in other $M$ types, such as M1 and M12 there were products of up to $12.3 \mathrm{~kb}$ (Fig. 1). Products $>7.5 \mathrm{~kb}$ in size indicated that a regulon was either multi-allelic (two or three emm or emm-L genes) or had regions of spacer sequence between the three genes.

In this work, RFLP within the virulence regulon for GAS was determined with seven DNA restriction endonucleases. The enzyme of choice, that gave the maximum discrimination among strains, was Hae III. To investigate the variation within the regulon of UK predominant $M$ types, clinical isolates were examined (Table 1). Those representing types M1 and M3 had similar RFLP patterns, in support of the general concept of their clonality and global dispersion [18, 36-38]. Furthermore, strains of M-type 11 may also be regarded as clonal within the UK on the basis of this study and PFGE [22]. Recent M1 strains differed from the prototype strain NCTC 8198 in not having a 1.25-kb fragment (Table 1; Fig. 3). It is not clear why this fragment was lost and whether or not it encoded a 'virulence' factor. The RFLP patterns for isolates representing the M5, M6, M12, M4, M(R)28 and M78 subtypes were heterogeneous. This is consistent with previous findings that some populations of invasive GAS are genetically diverse rather than of clonal origin. Similar variation within the same M5 and $M(R) 28$ strains was demonstrated by PFGE [22]. The data presented here, when compared with those from PFGE, suggest that long PCR typing of the virulence regulon from GAS may be more discriminatory. For example, M6 isolates gave closely related profiles on PFGE yet they could be further categorised into subtypes $6 \mathrm{~A}$ and $6 \mathrm{~B}$ on the basis of their virulence gene polymorphism (Table 1; Fig. 3) [22].

Two strains, NT 318 and NT 406, serologically Mprotein non-typable, were provisionally identified as M-type 6 by both long PCR and solid-phase emm 6 gene-specific oligonucleotide capture probe analysis. The presence of an emm gene in serologically Mprotein non-typable strains, as detected by the emm gene capture probe $(\mathrm{N}$. A. Saunders, unpublished observation), suggests that M-protein antigen expression is either attenuated or suppressed. It is expected that as more M-type strains are examined by long PCR, more M-non-typable GAS may be seen to have a virulence regulon profile characteristic of a particular $\mathrm{M}$ type.

The data presented here show that long PCR amplification and Hae III digestion of the virulence regulon from GAS can be used for the rapid and technically straightforward differentiation of M-type strains and of clinical isolates.

We are grateful to J. P. White for art work.

\section{References}

1. Eisenberg MJ. Rheumatic heart disease in the developing world: prevalence, prevention, and control. Eur Heart J 1993; 14: $122-128$.

2. Bisno AL. Group A streptococcal infections: the changing scene. Curr Opin Infect Dis 1995; 8: 117-122.

3. Stevens DL, Tanner $\mathrm{MH}$, Winship $\mathbf{J}$ et al. Severe group A streptococcal infections associated with a toxic shock-like syndrome and scarlet fever toxin A. $N$ Engl J Med 1989; 321: $1-7$.

4. Spencer RC. Review: invasive streptococci. Eur $J$ Clin Microbiol Infect Dis 1995; 14 Suppl 1: S26-S32.

5. Anon. Invasive group A streptococcal infections in Gloucestershire. Commun Dis Rep CDR Wkly 1994; 4: 97.

6. Anon. Invasive group A streptococcal infections: first report of enhanced surveillance. Commun Dis Rep CDR Wkly 1995; 5: 10.

7. Anon. Invasive group A streptococcal infections: second report of the enhanced surveillance scheme. Commun Dis Rep CDR Wkly 1995; 5: 123-124.

8. Roggiani M, Schlievert PM. Streptococcal toxic shock syndrome, including necrotizing fasciitis and myositis. Curr Opin Infect Dis 1994; 7: 423-426.

9. Nowak R. Flesh-eating bacteria: not new, but still worrisome. Science 1994; 264: 1665.

10. Lancefield RC. A serological differentiation of human and other groups of hemolytic streptococci. J Exp Med 1933; 57: 571-595.

11. Rotta J, Krause RM, Lancefield RC, Everly W, Lackland H. New approaches for the laboratory recognition of $M$ types of group A streptococci. J Exp Med 1971; 134: 1298-1315.

12. Gooder H. Association of a serum opacity reaction with serological type in Streptococcus pyogenes. J Gen Microbiol 1961; 25: 347-352.

13. Top FH, Wannamaker LW. The serum opacity reaction of Streptococcus pyogenes: frequency of production of streptococcal lipoproteinase by strains of different serological types and the relationship to M protein production. J Hyg 1968; 66: 49-58.

14. Top FH, Wannamaker LW. The serum opacity reaction of Streptococcus pyogenes. The demonstration of multiple, strainspecific lipoproteinase antigens. J Exp Med 1968; 127: 10131034. 
15. Widdowson JP, Maxted WR, Grant DL. The production of opacity in serum by group A streptococci and its relationship with the presence of $\mathrm{M}$ antigen. $J$ Gen Microbiol 1970; 61: $343-353$.

16. Skjold SA, Wannamaker LW. Method for phage typing group A type 49 streptococci. J Clin Microbiol 1976; 4: 232-238.

17. Tagg JR, Bannister LV. "Fingerprinting" beta-haemolytic streptococci by their production of and sensitivity to bacteriocine-like inhibitors. J Med Microbiol 1979; 12: 397-411.

18. Musser JM, Hauser AR, Kim MH, Schlievert PM, Nelson K, Selander RK. Streptococcus pyogenes causing toxic-shock-like syndrome and other invasive diseases: clonal diversity and pyrogenic exotoxin expression. Proc Natl Acad Sci USA 1991; 88: $2668-2672$

19. Musser JM, Gray BM, Schlievert PM, Pichichero ME Streptococcus pyogenes pharyngitis: characterization of strains by multilocus enzyme genotype, $M$ and $T$ protein serotype, and pyrogenic exotoxin gene probing. J Clin Microbiol 1992; 30: $600-603$.

20. Mylvaganam H, Bjorvatn B, Hofstad $T$, Hjetland $R$, Arne Hoiby E, Holm SE. Small-fragment restriction endonuclease analysis in epidemiological mapping of group A streptococci. $J$ Med Microbiol 1994; 40: 256-260.

21. Martin DR, Single LA. Molecular epidemiology of group A Streptococcus M type 1 infections. J Infect Dis 1993; 167: $1112-1117$.

22. Stanley J, Linton D, Desai M, Efstratiou A, George R Molecular subtyping of prevalent M serotypes of Streptococcus pyogenes causing invasive disease. J Clin Microbiol 1995; 33 2850-2855.

23. Bruneau S, de Montclos H, Drouet E, Denoyel GA. rRNA gene restriction patterns of Streptococcus pyogenes: epidemiological applications and relation to serotypes. J Clin Microbiol 1994; 32: 2953-2958.

24. Whatmore AM, Kehoe MA. Horizontal gene transfer in the evolution of group A streptococcal emm-like genes: gene mosaics and variation in Vir regulons. Mol Microbiol 1994; 11: $363-374$.

25. Podbielski A, Krebs B, Kaufhold A. Genetic variability of the emm-related gene of the large vir regulon of group $A$ streptococci: potential intra- and intergenomic recombination events. Mol Gen Genet 1994; 243: 691-698.

26. Chen CC, Bormann N, Cleary PP. VirR and Mry are homologous trans-acting regulators of $\mathrm{M}$ protein and $\mathrm{C} 5 \mathrm{a}$ peptidase expression in group A streptococci. Mol Gen Genet 1993; 241: 685-693.

27. Chen CC, Cleary PP. Complete nucleotide sequence of the streptococcal C5a peptidase gene from Streptococcus pyogenes. $J$ Biol Chem 1990; 265: 3161-3167.

28. Whatmore AM, Kapur V, Musser JM, Kehoe MA. Molecular population genetic analysis of the enn subdivision of group A streptococcal emm-like genes: horizontal gene transfer and restricted variation among enn genes. Mol Microbiol 1995; 15: 1039-1048.

29. Barnes WM. PCR amplification of up to $35-\mathrm{kb}$ DNA with high fidelity and high yield from $\lambda$ bacteriophage templates. Proc Natl Acad Sci USA 1994; 91: 2216-2220.

30. Pitcher DG, Saunders NA, Owen RJ. Rapid extraction of bacterial genomic DNA with guanidium thiocyanate. Lett Appl Microbiol 1989; 8: 151-156.

31. Cleary P, Retnoningrum D. Group A streptococcal immunoglobulin-binding proteins: adhesins, molecular mimicry or sensory proteins? Trends Microbiol 1994; 2: 131-136.

32. Perez-Casal J, Caparon MG, Scott JR. Mry, a trans-acting positive regulator of the $\mathrm{M}$ protein gene of Streptococcus pyogenes with similarity to the receptor proteins of twocomponent regulatory systems. J Bacteriol 1991; 173: 26172624.

33. Perez-Casal JF, Dillon HF, Husmann LK, Graham B, Scott JR. Virulence of two Streptococcus pyogenes strains (types M1 and M3) associated with toxic-shock-like syndrome depends on an intact myr-like gene. Infect Immun 1993; 61: 5426-5430.

34. McLandsborough LA, Cleary PP. Insertional inactivation of vir R in Streptococcus pyogenes M49 demonstrates that VirR functions as a positive regulator of ScpA, FcRA, OF, and $M$ protein. FEMS Microbiol Lett 1995; 128: 45-52.

35. Gardiner D, Hartas J, Currie B, Mathews JD, Kemp DJ, Sriprakash KS. Vir typing: a long-PCR method for Group A streptococci. PCR Methods Appl 1995; 4: 288-293.

36. Schwartz B, Facklam RR, Breiman RF. Changing epidemiology of group A streptococci infection in the USA. Lancet 1990; 336: $1167-1171$

37. Cleary PP, Kaplan EL, Handley JP et al. Clonal basis for resurgence of serious Streptococcus pyogenes disease in the 1980s. Lancet 1992; 339: 518-521.

38. Upton M, Carter PE, Morgan M, Edwards GF, Pennington TH Clonal structure of invasive Streptococcus pyogenes in Northern Scotland. Epidemiol Infect 1995; 115: 231-241. 